\title{
Tumor Antigen Gene
}

National Cancer Institute

\section{Source}

National Cancer Institute. Tumor Antigen Gene. NCI Thesaurus. Code C54306.

An antigen gene that is expressed in a cancer cell, resulting in the production of either a common tumor antigen or specific tumor antigen. 